\title{
Gifted Flows: Making Space for a \\ Brand New Beat
}

April K Henderson

\section{“The Contest"}

In a 1986 issue of the New Zealand literary journal Landfall, Albert Wendt published "The Contest," a portion of a proposed "verse saga" tentatively called The Chronicles of Vela, the Cooked. The poem is remarkable for many reasons, two of which I will reference here. First, it is Wendt's quite obvious attempt to demonstrate that Oceania can birth great and epic stories. The tale of sorcery, treachery, and bravery he introduces with "The Contest" brings to mind Western canonical texts such as the Iliad and the Odyssey; Oceania's mythical past, the poem implies, is every bit as grand as anything the West has to offer.

Second, "The Contest" is remarkable because with it Wendt crafts a profoundly hopeful vision of transnational cultural transmission, where inspiration and tools for survival are sought and adopted from beyond the Pacific, adapted, and deployed to fight very local, very personal battles. Wendt subverts the tendency (more prominent in Pacific settler colonial societies, it should be noted) to idealize mythic pasts in relation to a presumably debased cultural present. In his epic poem, it is actually inspiration from the non-Pacific present that invigorates a mythic Pacific past.

Set "primarily in pre-Christian, pre-Newtonian, pre-Papalagi [European] times" (Wendt I986, I 53, note), the poem is narrated by the young hero Vela ("cooked," in Samoan) as he recalls an encounter with the powerful orator Alopese of Manu'a. In Wendt's epic verses, Alopese is fearsome, awful, "halfatua halftagata born / of the Rock where the La rises and Tagaloa / hatched his human reflection ... the TuiManu'a's Lord of War ... Diviner of the Word who fattened on the mana / of defeated heroes ... Reader of the Future" (Wendt I986, I44-I45). ${ }^{1}$

The Contemporary Pacific, Volume 22, Number 2, 293-3 I5

(C) 2010 by University of Hawai' $i$ Press 
As the poem opens, Alopese defeats Vela's beloved companion Mulialofa and, as victor, demands from him his bones. From a thighbone, Alopese fashions a flute, playing arrogant tunes

while they unstitched each bone

from the house of Mulialofa's flesh

and tied together with sinnet a Bone-Man

white as smiling teeth who danced

one-legged to Alopese's fluting song (Wendt I986, I47)

Vela collects Mulialofa's discarded remains, builds a new frame out of wild pig bones, and nurtures the reconstructed flesh back to health. Though physically restored in the form of a Pig-Man, this modified Mulialofa remains emotionally inconsolable. He leaves Vela and wanders the mountains, searching for new verses "for a revenge he was never to exact" (Wendt I986, I48).

Vela vows to avenge Mulialofa, but to do so he must challenge Alopese to a contest of oratory. Vela's only option for honoring Mulialofa and retaining his own life lies in besting the mighty orator, verse for verse. Seeking to "catch a rhythm / a way a beat no one can imitate," Vela prepares for the battle by spending ten breadfruit seasons mastering all of the rhythms of his known environment. He learns the songs of sea creatures- "Then sky stone river creeper bird / tree dew lizard ant beetle"but remains unable to call forth a verse he is certain Alopese cannot match (Wendt I986, I48-I49).

The resolution for Vela comes in the form of a dream. "In the river that was dream," Vela becomes the pe'a, or flying fox, the indigenous Pacific Islands fruit bat that occupies a key position in both Samoan legend and Wendt's contemporary fiction. It is the pe'a, whose mythical powers enable it to traverse the vā (the void or space between time, place, and people), who becomes the vessel through which Vela learns the new beat he desperately needs. As flying fox, Vela is lifted out of the pre-Christian, pre-Newtonian, pre-European Pacific past, and hovers "in the white stillness / and the stench of acid fire" over a contemporary postindustrial city. He soars "above a reef of cloudhigh dwellings / with millions of eyes and fissured / with deep chasms like dry riverbeds," before descending into this surreal landscape of steel and song:

I dropped lower and in one of the chasms

black youths in exotic hides gyrated 
to a black singing box to a beat I'd never heard

like the rapid shatter of rain or branches breaking in strong winds to a voice chanting an imagery

both savage and hypnotically direct muscled like jabbing spear arms (Wendt I986, I49)

In his "gifted flow of dream," Vela nets the powerful imagery and beat of these urban black youth inside his "upside-down flyingfox head" and returns to the mythic past to engage Alopese in a battle of verse (Wendt I986, I49).

Flanked by the chiefly TuiManu'a and the grotesque dancing Bone-Man, the haughty Alopese sneers at the proposed contest until reminded that he cannot refuse Vela's challenge. "Gather round kings and aristocrats of our land," the fledgling orator begins, "and listen to my brand new beat":

I'm a boly rock'n'roller

looking for a seat in Lord Tagaloa's

ferocious band I'm a boly rock'n'roller

eager for revenge

So, c'mon Alopese and your toothlessly

scared Bone-Man there's a new beat rolling

through this empty nobody land (Wendt I986, I 50; italics in original, here and later)

Vela's "brand new beat" leaves the experienced orator speechless. Alopese is caught unprepared by Vela's verse, struck down by this echo of James Brown.

"You want to dance Bone-Man," Vela continues, addressing the travesty that was his beloved Mulialofa. "So dance to my rocking beat from / the land of the acid dead / I'm a holy rock'n'roller eager for revenge." In a series of moves clearly drawn from the initial mid-ı980s global popularity of American hip hop dance-“backslides headspins turtling”- the skeletal dancer succumbs to Vela's funk-laden web of rhythm, but cannot sustain movements requiring muscle, sinew, and heart. The Bone-Man break(dance)s himself to pieces (Wendt I986, I 5 I).

"Defeat him!" the TuiManu'a orders Alopese, but his Lord of War cannot. "He tried and tried / but my beat wasn't in his knowing in / his air or in his future" (Wendt I986, I 5 I). Vela wins the contest and, in vic- 
tory, demands of Alopese his voice. The TuiManu'a slits Alopese's throat, reaching "down through / gullet into the temple depths / of chest heart and moa," down into the center of Alopese's being, to grasp his voice and wrench it "up and out / into the circling gasping air" (Wendt I986, I $5 \mathrm{I}-\mathrm{I} 52$ ). Unable to match a beat outside his knowing, outside his future, Alopese must submit his voice to Vela, herald of the new.

I knelt and the TuiManu'a's red-

flowing hand clasped and covered

my in-sucking mouth releasing

Alopese's voice his mana to surge

like Tagaloa's breath that gave us life

down down

into all that I was am

and will be in the Unity that weaves

winner and loser

conjurer and conjured

artifice and reality illusion and fact

in the fatal game in the endless dreaming of the dream (Wendt I986, I 52)

In the act of consumption, in the process of sucking Alopese's voice into his body, Vela weds that voice to the very newness-the new beat, the new rhythm - that defeated it. Neither does Vela's act entirely destroy the vanquished orator, in the sense of complete erasure, nor does it preserve him as any unchanging same. Vela simply ensures that Alopese's voice, his mana, is retrieved from an impossible future and returned to circulate in the pool of possibility.

As the poem closes, Vela dances in unity with all of the manifestations of himself, his companion Mulialofa, and his rival Alopese. "Tonight Mulialofa Alopese Bone-Man / Pig-Man and the Holy Rock'n'Roller / that I inelegantly was / dance again around the healing / togo fire burning as slowly / as the last rising dawn" (Wendt I986, I 52 ). In this final stanza, it is fitting that the characters circle a fire of togo (mangrove) wood. Like the mangrove that crucially exists in the liminal ebb and flow of salt and freshwater, not quite of the land and not quite of the sea, "The Contest" blurs binary distinctions. In the piece, "winner and loser, conjurer and conjured, artifice and reality, illusion and fact" all necessarily exist as parts of a unified whole. Divisions between past, present, and future bleed. The postindustrial future-which for the reader is quite likely the 
temporal present-informs the preindustrial past, and precolonial practices are invigorated with postcolonial potential.

In "The Contest," the flying fox represents what, for Wendt, remains an absolutely vital component of the native Pacific: the power of imagination. It is this figure of indigeneity, the pe'a, that facilitates imaginative travel and access to an alternative world outside the Pacific, and it is the possibilities presented in this alternative world that subsequently enable Vela to resolve his very local predicament. The "new beat" netted in Vela's "gifted flow of dream" can be read as both destroying and preserving the indigenous knowledge, power, and tradition signified by Alopese's awesome voice. "The Contest" suggests that indigenous Pacific futures can be understood in relation to urban, postindustrial, Afro-diasporic popular cultures, but the poem also implies that such cultures necessarily already influence the contemporary articulation of indigenous Pacific pasts. Narratives of the past, in other words, are already being delivered with new vocabularies, over new beats and new rhythms.

\section{SAMOAN / Hip Hop/Diaspora}

For reasons I explain a bit later in this essay, Albert Wendt's epic poem "The Contest" has, for over a decade, remained a source of inspiration for my research on Samoan involvement in hip hop culture. Hip hop-music, dance, and visual art-is one of the many transplanted popular cultures that have taken root in Pacific Islander communities. Hip hop participation is particularly notable in both the urbanized communities of the Pacific Rim where Islanders have settled and, increasingly, in the islands closely connected to those communities by patterns of circular migration. Of all the Pacific peoples participating in hip hop, Samoans are notable for the sheer number of artists currently active, for their relative degrees of commercial success, and for the geographic range where these artists can be found.

The three-decade history of Samoan exposure to and participation in hip hop culture across the Pacific is closely tied to at least five decades of relatively large-scale Samoan movement and migration between rural island villages and urban industrial cities in the continental United States, Hawai'i, Aotearoa/New Zealand, and Australia. The significant sites of Samoan urban residence are dispersed in an expansive radius, geographically distanced from the Samoan "homelands" of Sāmoa and American 
Sāmoa. Despite the distances, connections between these sites and the Sāmoas, and between the sites themselves, are maintained daily through travel, telecommunications, circulating people, media, commodities, and ideas. What ethnographic photographer Frederick Sutter once termed the "global family" of Samoans retains strong material—and perhaps even stronger emotional-connections between nodes (Sutter 1989). Echoing the work of prominent Pacific Islands intellectuals (Hau'ofa I993), George Marcus aptly summed up the situation: "In certain areas of the worldparticularly island areas such as the Pacific-European penetration merely added a larger dimension to an existing tendency for local populations to view their social worlds in broad geographical terms" (I998, I36; see also Salesa 2003). As one Los Angeles resident, originally from independent Sāmoa, succinctly asserted, "We're still navigating, just not by boat" (Mona Porotesano, quoted in Gregory 2005).

Hip hop, in all its elemental manifestations-music, dance, and visual art-travels even more extensively. For nearly three decades now, hip hop has provided an important outlet for the creative talents of the Samoan diaspora in the United States and Aotearoa/New Zealand. ${ }^{2}$ While the small but growing body of literature on hip hop practices outside the United States tends to highlight the early influence of imported American music, movies, and television programs (Mitchell 1996, 200I; Basu and Lemelle 2006), for Samoans, at least, initial hip hop exposure was also partially the result of knowledge passed person to person along the expansive networks of kin connecting California, Hawai'i, American Sāmoa, Sāmoa, and Aotearoa/New Zealand (Henderson 2006, 2007; Kopytko I986, I99I; Scott I985). Today, many of the most prominent hip hop musical artists of Pacific Islands descent are Samoan, ranging from the Boo-Yaa T.R.I.B.E., DJ Kutfather, Brownsville, or Samoan Irok in California, to members of 'Āiga, B.E.T., Samoan Dynasty, or the production team Slapp Symphony in Hawai $i$, and the extraordinary regional successes of Scribe, Mareko, Savage, Dei Hamo, PNC, David Dallas, Ladi 6, and Tha Feelstyle in Aotearoa/New Zealand. Additionally notable is the special niche popularity of Sāmoa's Zipso and Mr Tee, or Samoan-Tokelauan Vaniah Toloa, among Island-based youth and Samoan-speaking populations worldwide. Less commercially visible but just as talented are the many Samoan dancers and graffiti artists who are also integral contributors to hip hop culture.

The widespread embracing of hip hop by young Samoans has not gone uncontested, however. Over the past twenty-five years, Samoan hip hop 
artists have faced criticism from other Samoans who view hip hop as a threat to fa'a Sāmoa; from whites who see Samoan hip hop practices as nothing more than sad mimicry by increasingly inauthentic "natives"; and from African Americans seeking to guard a cultural territory to which they claim racially privileged access. Samoan elders in California have likened community youth adoption of hip hop style to "a phase of selfdenial," during which young Samoans, ashamed of their own heritage, were "purposefully emulating other minority groups' speech patterns and clothing styles, particularly African American" (Pouesi 1994, 86). Similar sentiments have been expressed in Hawai'i, where youth have been derided for "coming back from California talking like blacks and acting like Mexicans" (Emmsley 1996). Such discourses of inauthenticity also echo outside the Samoan community, such as travel writer Paul Theroux's characterization of the Boo-Yaa T.R.I.B.E. as a "quintet of shaven-headed fatties, [who] had made a fortune in Los Angeles imitating black rappers" (I992, 323). The ethno-nationalistic claiming of hip hop by African Americans has also challenged Samoan hip hop production, with the most acute charges of inauthenticity laid during the late I980s-early I990s when the influence of Afrocentric and black nationalist ideology was strongest in American hip hop. For Samoans recording and performing in the continental United States, in the midst of substantial AfricanAmerican populations, such challenges were deeply felt. Of many possible examples is the classic Boo-Yaa T.R.I.B.E. track "Psyko Funk," from their I990 debut album New Funky Nation, which humorously but defiantly narrates the group's justification for why, as non-blacks, they still have a right to make rap music.

Recalling the terminology developed by Stuart Hall and his coeditors in their elaboration of the creation of public perceptions of crime and crises (1978), the very phrases "hip hop" or "rap music" often possess a strong "referential context" for many people; they are frequently wedded to another provocative term, "gang," in private and public discourse about youth crime. The fact that the youth considered disruptive are often clad in urban American clothing styles and accompanied everywhere by booming bass lines is not lost on observers both inside and outside Pacific communities. While relationships between rap music and behavior have long been debated by academics (De Genova 1995; Kelley 1994; Rose I994), community certainties that hip hop is contributing to gang mayhem persistently echo everywhere. Such sentiments posit hip hop culture as antithetical to traditional Pacific Islands cultures, and as a worrisome 
influence that diverts young people from proper behavior (O'Malley 2006; Field 2007; Stokes 2005; Rees 2007).

Discourses of cultural contamination have a powerful resonance and can be invoked by both Samoans and non-Samoans to address perceived changes in the attitudes, behaviors, modes of comportment, styles, and tastes of Samoan youth. While instances or patterns of disruptive behavior among Samoan youth certainly warrant critique, it is perplexing that often such critiques too easily identify the influence of a contaminating, racialized Other (African Americans) or the Other's cultural production (hip hop) as the source of the problem. It is useful to note, for instance, that New Zealand's worst era of gang-related violence occurred in the I970s, before hip hop culture arrived. Then, as now, imported American popular media may have provided visions of outlaws and rebels (in this case white bikers rather than black Bloods and Crips), but it was people's lived experiences at the interface of local and global structures of inequality that rendered those visions compelling. Labeling hip hop the root, the origin, of disruptive and dangerous behavior now-whether in the United States or abroad-obscures pressing social problems by presuming that hip hop is the cause of those problems rather than another effect. "Hip hop," as a terminological net burgeoning with slippery, flip-flopping referents, becomes a fuzzy focal point for a range of anxieties and fears about cultural change.

Despite being buffeted by criticism on all sides, there seem to be more Samoan hip hop artists now than ever. ${ }^{4}$ These artists explicitly and implicitly respond to such challenges, staking claims for the validity of their cultural practices. While it is commonplace in prominent cultural studies scholarship to question notions of authenticity-think of the work of Paul Gilroy (1987, I993a, I993b, 2000), or Stuart Hall (1990, I991a, I99Ib, I992), for example-students of either Samoan or hip hop cultures cannot afford to ignore the ways in which those notions continue to have great salience. If attempting to arbitrate authenticity is a misguided academic endeavor, examining the cultural effects of other people making such attempts, as Gilroy's work does, is not.

My greatest aim in my research and writing is to do justice to both of the very strong, very proud-but very different-types of cultures at the center of my work. One, "Samoan culture," is that of the indigenous people of the Samoan Islands, whose descendants number some four or five hundred thousand people worldwide. Some of this culture's elements date back millennia, many are reworked every day, but the culture never- 
theless commands recognition, from both insiders and outsiders, that it is a culture and has been for a very long time. At a time when the term "culture" is used loosely to describe the activities and ethos of all types of environments ("corporate culture," "car culture"), "Samoan culture" meets expectations about what a culture is in the strictest ethnographic sense.

The second culture also, according to some, incorporates elements dating back millennia, but most commentators contend that it only knit together as a recognized culture unto itself in the past thirty-five years. The facts of hip hop culture's spatial and temporal development-which initially gelled in I970s New York City-render it too young, too urban, too much a product of the West to carry the same weight as "Samoan culture" in ethnographic imaginations. In some quarters, hip hop's status as a culture worthy of analysis is still questionable enough to elicit significant debates when researchers receive funds to study it. ${ }^{5}$ Yet hip hop culture has a significant influence on hundreds of thousands, even millions, of people, and is important enough in many hip hop artists' lives that they rank it as an equal or greater component of their identity than their ethnic, national, or any other culture that they may affiliate with. Samoan artists are no exception. High Chief XL (Walter Sāole), an emcee with the Honolulu-based hip hop group 'Āiga and now in his mid-zos, explained:

Hip hop ... it's basically my life. ... Hip hop has always been an integral part of what I do, what I listen to, how I dress, how I talk, I mean, that's just me already. I live hip hop. There are certain things you can be infatuated by, "Oh, I want this," but then something you carry throughout your life, that's you, that's the definition of you, already. Basically. That's how hip hop is. It's a part of my life. If you cut me up into pieces, one piece would have to be for hip hop. (quoted in Henderson I999, 6I)

Wellington-based dancer and graffiti writer SpexOne (Sara Tamati), a New Zealand-born Samoan raised in Christchurch, similarly cited hip hop as integral to the development of a flexible and effective positionality situated at the nexus of a range of gendered, cultural, familial, and occupational responsibilities:

I've got this foot in this Samoan world where I have this role as the older daughter, and an older sister, [but] I am also in this hip hop world [where] I have learned all this confidence of being an individual, putting myself on the line, and . . battling, putting my [graffiti] pieces out in public arenas where people can critique it. . . . So I've been able to take that confidence into this other world: say, I take my hip hop confidence and take it to work. ... if I'm 
even at home, I've got a whole different inner confidence that I never used to have when I wasn't involved in hip hop. (Tamati 2009)

Such statements challenge assumptions that these artists' ethnic culture necessarily trumps their various other cultures in the composition of their identity(ies), or in the ways such identity(ies) translate into action in daily life.

\section{Gifted Flows: Making Space for “A Brand New Beat”}

For over a decade now, "gifted flows," derived from the "gifted flow of dream" that enables Vela to navigate the vā between worlds in "The Contest," has remained for me an enduringly evocative phrase. In contrast to the ready dismissals and denigrations of hip hop culture voiced elsewhere, Wendt's poem explores the ways Afro-diasporic popular music and dance (and, though Wendt doesn't reference it, visual art) can be adapted into Pacific Islands contexts. The gifted flows suggested by the poem are transnational, transcultural acts of imagination; it is Vela's "gifted flow of dream" that enables spatial and temporal worlds to be traversed, and words to be shared. As a result of this fantastical instance of cross-fertilization, Vela is rendered capable of the powerful oratory necessary for defeating the formidable Alopese in a traditional contest of verse.

Lifted from the context of "The Contest," but in keeping with the themes explored in that piece, the salience of the phrase "gifted flows" renders it exceptionally apt for the relationships I have endeavored, over the past twelve years, to both describe and analyze in my academic work on the movements of hip hop culture in and through the Samoan diaspora. "Gifted" might be read in the sense of "talented" or "skilled," referring to a person's individual abilities. Over and above these terms, however, "gifted" struggles to convey something unknowable, untranslatable, and indescribable. Implicit in the term is an added dimension of ability attributable to the divine. It hints toward a God or gods, a giver of gifts, a force outside of humanity that makes the impossible possible and brings unfathomable beauty into the world. Yet, the "gifted" individual is not akin to the figure of the nineteenth-century European composer, the "semidivine being, struck by holy inspiration, and delivering forth ineffable delphic utterances" (McClary I 98 5, I 56), for she or he is tethered in my imagination to other interpretations of the term.

In these other meanings, "gifted" the adjective shifts to "gifted" the 
transitive verb, which can also mean "bequeathed," "passed down," or "passed on." Music can be gifted, stories can be gifted, knowledge can be gifted. People can also be gifted, at least in the sense that the shifting collections of narratives, attachments, and material effects webbed around the sign of the proper name can pass from one person to another (readers might reflect on who first "gifted" them with Albert Wendt, for instance: who ushered his work into your life?). "Gifted" also invokes the reciprocal relationships continuously cemented by gift exchange-relationships central to many Pacific Islands societies. Gift recipients are indebted to, tied to, brought within the orbit of those from whom they receive their gifts. Thus, the gifted individual, or the individual working with gifted mediums, is necessarily and inseparably situated within the multiple communities from which they and their work draw. They are not apart from politics, economics, history, or social life. Their mana is precisely their capacity to imaginatively rework the traditions from which they spring.

"Flows" similarly resonates on multiple levels: flows of people, flows of music, flows of words. The term suggests "currents": electrical currents, ocean currents. "Currents" in turn suggests "waves": sound waves, sea waves, waves of Islanders crossing waves of ocean responding to waves of music with waves of motion. The term "flows" has a particular usage in hip hop culture, where it speaks to an emcee's unique ability to "flow" rhymed lyrics to beats. The seductive power unleashed in such flows is suggested in "The Contest" by Vela's successful defeat of Alopese and destruction of the Bone-Man. That power is also confirmed by the contemporary global significance of hip hop music.

"Flows" also has burgeoning currency in academic analyses of the processes of globalization, where it serves as a usefully ambiguous and loose term to describe the transnational movements of populations, capital, material goods, services, and ideas. Arjun Appadurai remains one of the most articulate-and hopeful—of those utilizing concepts of flow to conceptualize these movements (1986, I996). I am similarly concerned with juxtaposing the movements of mediating bodies and mediated sound and imagery. Hip hop media moves with people and between people; and, importantly, people move and mediate hip hop.

A Samoan alagā'upu states, "E pala le ma'a 'ae lē pala le 'upu (Even stones decay but words endure)" (Allardice I985, 2 г 8). A Hawaiian 'ōlelo no'eau shares a related sentiment: "I ka 'ōlelo no ke ola, i ka 'ōlelo no ka make (Life is in speech, death is in speech. Words can heal; words can destroy)" (Pukui I983, I29; italics in original). Both proverbs point to 
the centrality of utterance in societies that, prior to missionization, relied on the oral mediation of power and authority. Wendt and many of his fellow Oceanic writers and educators-such as those editing and contributing to this volume-are invested in and committed to the power of the written word to similarly mediate power in the contemporary period. For these Pacific writers, art is politics and politics is art. As Hawaiian activist, intellectual, and poet Haunani-Kay Trask stated: "I do not perceive the world of creative writing as divided into categories of prose and poetry or fiction and non-fiction. Nor do I imagine myself crossing from political resistance into artistic creation and then back again. Life is a confluence of creativities: art is fluid political medium, as politics is metaphorical and artistic ... Perhaps this is a traditional Polynesian, or Native, view. Our Hawaiian chiefs, for example, announced war through the use of ominous metaphor; and woe to those who misunderstood the chiefly references" (1999, I 8; see also Wendt 1987).

In "The Contest," Alopese, Mulialofa, and Vela also announce war through the use of ominous metaphor. Their oratory, their poetry, has devastating consequences. What is perhaps most interesting about "The Contest" is that it is a written poem struggling-battling, even—for the future of orality in the Pacific: orality not simply in the sense of a valorization of indigenous oral traditions, but also in the sense of the ability to enunciate and articulate complex understandings of self and community. The poem finds its hope, indeed, its weapon, in a contemporary popular music form marked most significantly as African American. In popular music, Wendt posits a form of oral culture with the power to reshape, reinvigorate, and revive Oceania. The marriage of words with beats potently stirs pools of possibility, destroying, creating, and remixing the old world to spin it anew.

The saga of Vela in "The Contest" provides interesting echoes, albeit in a different register, of some of Wendt's earlier writings. In light of the community anxieties about hip hop noted earlier, his important 1976 essay "Towards a New Oceania” provides useful critiques of the perpetual damage of racialized discourses of contamination in the Pacific Islands. In that essay Wendt attributed such discourses to the continuing impact of European colonialism, and interrogated the guises they assume: "Many of us are guilty-whether we are aware of it or not—of perpetuating the destructive colonial chill, and are doing so in the avowed interest of preserving our racial/cultural purity (whatever this means)" (Wendt I976, 54). Wendt also suggested something of a prescription for the future. He 
stressed that knowledge of Pacific pasts alongside knowledge of other peoples and their cultures together form "a precious source of inspiration for living out the present.... The only valid culture worth having is the one being lived out now. . . . It won't do to glorify the past. The present is all that we have and we should live it out as creatively as possible" (Wendt I976, 54). Or, as Vela sings:

\author{
We are the remembered cord \\ that stretches across the abyss \\ of all that we've forgotten \\ We don't inherit the past \\ but a creation of our remembering (Wendt I986, I44)
}

Wendt, the foremost Samoan cultural and intellectual writer and critic, has been attentive throughout his career to the dynamic tensions between Samoans, other Pacific Islanders, and peoples of African ancestry. Thirteen years before publishing "The Contest," he made his auspicious debut on the Pacific Islands literary scene with Sons for the Return Home (I973). Heralded then and since as "the first Samoan novel," this remarkable text is an intimate and painful exploration of one migrant Samoan family's experiences of life and labor in early i970s New Zealand. Of the many memorable scenes in the novel, one deserves mention here.

The young male protagonist of the novel, the "son for the return home" who embodies all of his parents' hopes and desires for success in New Zealand and eventual return to Sāmoa, tells his Pākehā (non-Māori, in this case white New Zealander) girlfriend of the bitterness and violence existing among Samoans, indigenous Māori, and other Pacific Islanders in New Zealand. "You would think, because Maori and Islanders are at the bottom of the social and economic ladder here, we would be brothers. But the sad fact is we're not" (Wendt I973, 98). Immediately following this statement, the character relates an incident that puts inter-Polynesian animosities into a more expansive global frame, pointing to the persistent limits of the era of decolonization:

Last year at university, an African student gave a lecture on racism in New Zealand. For over an hour he accused, condemned, and flagellated the pakeha; and I grew drunk with self-righteous anger. At question time a nervous pakeha housewife asked who had discriminated against him in the worst way. I awaited his answer eagerly, hungrily. "PAKEHAs!" I expected him to spit out. You know what he said-sadly, almost as if he didn't want to betray his own colour, his 
own kind: “ISLANDERS AND MAORIS!" Lies! I wanted to shout at him. Another Samoan student sprang up and took the word right out of my mouth. The African, magnificent in his traditional robes-and I can see him now in all his truth-just smiled, looked down at him and said, "You know the score, brother.” Paused. Walked off the stage. (Wendt I973, 98)

For all the hope, the potential, and the possibility that the phrase "gifted flows" intimates, the above passage from Sons for the Return Home must sit alongside it, giving us pause. There is undeniable identification and inspiration being drawn by Samoans and other Pacific Islanders from peoples of the African diaspora and their cultural production, but in the communities in which there is ample opportunity for interaction, Samoan and African or African-American relationships are also often marked by wariness, tension, and occasionally violence. Elsewhere, in places where Islanders consume rap music in the absence of African-American populations, a dangerous, if well-meaning, naiveté about the larger context of hip hop culture may persist-one of the problems inherent in reading the articulations of primarily urban males, ages $\mathrm{I}_{4}-35$, as representative of African-American experiences as a whole. ${ }^{6}$ For both his visions of hope and his many cautions, Wendt's work remains a source of inspiration.

\section{Toward a Pacific Hip Hop Arts Movement: Staging Hip Hop in Aotearoa}

In I993, a theatrical adaptation of Albert Wendt's “The Contest" was staged by Pacific Theatre Company in Auckland, New Zealand, a city often heralded as having the largest urban concentration of Polynesians in the world. The play, from a script by playwright Paul Simei-Barton, took some artistic license with Wendt's work, splitting the protagonist Vela into two parallel characters. ${ }^{7}$ One Vela, in keeping with Wendt's original, is an orator's apprentice in "Polynesia in the mythical period," while the other is a hip hop-loving youngster in contemporary South Auckland. The denouement of the play, as in the poem, is that the orator's apprentice is able to vanquish the dreaded enemy who defeated his companion Mulialofa by utilizing a "brand new beat" gleaned from African-American popular music.

Drawing out the provocative implications of Wendt's poem, the staged version of "The Contest" rendered hip hop-by then a ubiquitous presence in Auckland-more explicit in the material. Simei-Barton's script 
turns an interesting twist on the poem, however, in that the Vela of the mythical period does not become the flying fox in his dream, and is not transported across the vā, the temporal and spatial void, that separates him from the African-American postindustrial city. Rather, the pe'a-a separate entity-enables the orator's apprentice to receive his brand new beat from what ostensibly is himself in the alternate temporal/spatial universe of deindustrializing South Auckland.

In the play, the pe'a (now gendered female) visits the Vela in contemporary South Auckland and takes back what she has learned, in this case the beats and rhyming styles of hip hop, to the Vela in mythical Polynesia, teaching him through his dreams. An oratorical contest ensues between the apprentice Vela and the powerful orator Alopese that is inspired as much by a modern freestyle rhyme battle as it is by gagana fa'afailāuga (traditional Samoan oratory; see Simanu 2002). ${ }^{8}$ African Americans still figure in the play, but in the form of the commoditized recordings by US rap artists (Ice-T is one example) that permeate the public and intimate spaces of urban New Zealand. Thus the play introduces additional layers between Vela and what might be perceived as an "original" AfricanAmerican popular culture.

I am interested in the ramifications of introducing yet another layer to the mythical Vela's source of transcultural inspiration. Pacific Islander involvement in hip hop in Aotearoa has over twenty years of history; Vela's brand new beat is by now "old school." Today, young Samoans and other Pacific Islanders in South Auckland and around the country continue to respond to hip hop music and dance, but, increasingly, the commoditized hip hop recordings that they consume are being produced by themselves or other Pacific Islanders in Aotearoa/New Zealand, Australia, Sāmoa, Hawai'i, or the continental United States. Hip hop is not just a thread potentially connecting them to African Americans and the many others who have contributed to forming the culture; it is a thread that potentially binds Samoans to each other across the broad geography of their dispersal-as recent collaborations between US and NZ-based artists attest. ${ }^{9}$ Hip hop is one of many ways to reach across the vā and articulate connection in the diaspora.

While it was Paul and Justine Simei-Barton and their Pacific Theatre Company who adapted and updated Wendt's poem "The Contest" for the stage, Wendt subsequently tried his own hand at including hip hop elements in his first play, The Songmaker's Chair. Written in the mid-to-late I990s and first performed in Auckland in 2003, the play centers around 
members of the New Zealand-based Peseola family, including the family's Samoan patriarch, his Samoan wife, and their four children, Māori son-inlaw and pālagi daughter-in-law, and two grandchildren. Displaying continuity with Wendt's earlier fiction, the play weaves together the hopes and heartaches of their experiences of migration and, as Wendt writes in his introduction to the published play, "the conflicts and passions, the alofa and loyalty, the fears and secrets of this family" (Wendt 2004, 2).

In a manner also quite in keeping with "The Contest," Wendt has made space in the play for potentially fertile mixtures of old and new where hip hop, or specifically rap music, figures significantly: "Like the Peseola family, our journeys have been from our ancient atua [gods] and pasts to the new fusion and mix and rap that is now Aotearoa and Auckland" (Wendt 2004, 2). The play includes a notable section in Act Three, Scene Four, in which the youngest characters-the twenty-five-year-old Samoan-Māori granddaughter and her twenty-year-old brother-compose and begin delivering a rap about the family's history:

'O Peseola le Suafa 'o le 'āiga nei,

Peseola Peseola is the name of the way,

Peseola Peseola is your way to fame

So get up, sister, and join the play,

Get up, brother and be part of the game

They are soon joined by the rest of the family, who improvise their own verses, weaving between English and Samoan to tell familial narratives of migration experiences.

I saw The Songmaker's Chair when it was staged in Wellington, as part of the 2004 International Arts Festival. At Victoria University, I have also assigned sections of the play, along with the poem "The Contest," to students in my third-year special topic course in Pacific studies, which examines Pacific hip hop narratives of identity and belonging vis-à-vis conceptions of ethnic and national culture (for example Samoan or Tongan culture) as well as in relation to the popular culture of hip hop. I believe it is important for students to see that Wendt, whom most regard as an elder and therefore subject to all the assumptions they typically make about their elders, has actively attempted to not only recognize but also to embrace hip hop in his work for over twenty years. Wendt's slightly cumbersome attempts at hip hop lyricism in "The Contest" and The Songmaker's Chair might never best the likes of Scribe, Mareko, or Wellington's Juse in an emcee battle, but that's not the point. I encourage my students to explore 
the stakes of Wendt's space-making gesture-his metaphorical afio mai, beckoning hip hop onto the malae of Pacific cultural production. In fact, I choose to read Wendt's non-mastery of hip hop rhyme patterns as perhaps one of the best testaments to the existence of hip hop as a culture, possessed of its own rich nuances, textures, histories, and fiercely cherished codes for being in the world: for all of his deep appreciation and indisputable poetic talent, Wendt heralds, but does not quite capture, the "brand new beat" in his writing.

For over two decades now, Albert Wendt has consistently proved willing to both engage and accommodate hip hop. His engagements are literaryas he invokes or attempts to harness hip hop in poems, plays, and novels-but they have also been quite literal. In I999, I asked a close friend, the aforementioned High Chief XL of the group 'Âiga, to rhyme several verses as part of my presentation at the Center for Pacific Islands Studies annual conference in Honolulu. Immediately following my paper, Wendt publicly thanked the emcee and spontaneously invited him and his fellow group members to stay at his house should they ever visit Aotearoa. Like hip hop culture itself, Wendt's Vela project never went away; more than twenty years since penning and first publishing the poem "The Contest" in the journal Landfall, Wendt has at last completed an expanded version of his heroic epic, The Adventures of Vela (2009). It was announced during the final edits of this special issue that Vela won the Commonwealth Writers' Prize for the Southeast Asia and Pacific region.

Hip hop culture is alive and well in Aotearoa-and has been for nearly three decades-but an incipient hip hop arts movement, bringing the aesthetics of the urban street to the literary and performing spaces of "high art," is still being born. Wendt has opened important space that others (including Pacific Theatre in the I990s, Christchurch's Pacific Underground from the I990s to present, and Auckland's Kila Kokonut Krew since 2005) can imaginatively inhabit with their own complex, creative articulations of self and community. ${ }^{10} \mathrm{~A}$ door stands ajar. If tonight a pe'a should again hover over a far-off postindustrial city (perhaps New York, or San Francisco?), she might gaze down through the reef of cloud-high dwellings and see and hear not just music and dance but an entire, burgeoning arts movement of poetry and literature and theater inspired and informed by the aesthetics of hip hop culture, and crafted by those who call that culture home. And somewhere in Aotearoa, in a gifted flow of dream, a talented young Samoan member of the hip hop generation is capturing it all in her or his flying-fox head and heart. 


\section{Notes}

I The TuiManu'a is the paramount chiefly title of the Manu'a Islands Group in the eastern Samoan chain, and holders of this title have been historically important in the wider central Pacific region (Sāmoa, Tonga, Fiji). Mana is a pan-Polynesian concept of divinely sanctioned power and efficacy. One source notes its definition in relation to Māori as "ancestral power, presence; influence; prestige; authority" (Sissons I99I, 292).

2 For a survey of literature on Samoan migration, see Macpherson 2005.

3 See Theroux's 1992 travel book The Happy Isles of Oceania. His physical description is blatantly inaccurate (rather than being "shaven-headed," one of Boo-Yaa's enduring signature styles is long braids). As evident elsewhere in the book, Theroux is also given to hyperbole when discussing the extent to which they "made a fortune" with their music.

4 Rappers are especially prolific. Twelve years ago, when I began researching Samoan hip hop, a fairly complete list of all the Samoan rap artists recording in the continental United States and around the Pacific seemed possible. However, with the increasing accessibility of recording technology and independent distribution networks via the Internet, this is no longer the case.

5 See Whimp 2007-2008 for an analysis of the negative and inflammatory publicity surrounding a recent international study (2003-2004) on links between hip hop culture, entrepreneurialism, and social development opportunities for participants.

6 Consider, for example, the mistaken belief that usage of the term "nigga" in US-produced rap music means that the term is widely acceptable among all sectors of black American populations. See Julien I 994 for a critical discussion of the circulation and reception of US-produced rap and Jamaican-produced dancehall music.

7 Pacific Theatre was founded by Samoan playwright and filmmaker Justine Simei-Barton. Simei-Barton's creative partner and husband, Paul Simei-Barton, is of European ancestry.

8 A definition: "Freestyling is the ability to rhyme straight from the top of your head, as opposed to rappin' lyrics which have been previously memorized, or 'from page' as some emcees would word it. Done to a funky instrumental beat, or to a human beatbox, even done a capella, it is rapping in its freest form and where rap, as we know it today, has evolved from" (T-Love, quoted in Cross 1993, 305-306).

9 The album Savage Island by New Zealand-based artist Savage is a salient example of trans-Pacific Samoan collaboration (2008).

Io Kila Kokonut Krew's Vela Manusaute took the name Vela after performing in Pacific Theatre's 1993 staging of “The Contest." 


\section{References}

Allardice, $\mathrm{R} \mathrm{W}$

I985 A Simplified Dictionary of Modern Samoan. Auckland: Polynesian Press.

Appadurai, Arjun

I986 The Social Life of Things: Commodities in Cultural Perspective. Cambridge, uk: Cambridge University Press.

I996 Modernity at Large: Cultural Dimensions of Globalization. Minneapolis: University of Minnesota Press.

Basu, Dipannita, and Sidney J Lemelle, editors

2006 The Vinyl Ain't Final: Hip Hop and the Globalization of Black Popular Culture. London: Pluto Press.

Boo-Yaa T.R.I.B.E.

I990 New Funky Nation. Audio CD. New York: 4th \& B’way.

Cross, Brian

I993 It's Not About a Salary ... Rap, Race + Resistance in Los Angeles. London: Verso.

De Genova, Nick

I995 Gangster Rap and Nihilism in Black America: Some Questions of Life or Death. Social Text 43:89-I32.

Emmsley, Leusogafofoma'aitulagi William

I996 Public address given at East-West Center, Honolulu, 3 I October.

Field, Michael J

2007 Youth Gangs Represent Real Security Threat in Pacific. 24 July. Reprinted on LeSpecula.com International News Weekly. http://www.laspecula .com/index 2.php?option $=$ com_content $\&$ do_pdf $=\mathrm{I} \& \mathrm{id}=\mathbf{2 6 9}$ [accessed

Gilroy, Paul 23 October 2009]

I987 “There Ain't No Black in the Union Jack": The Cultural Politics of Race and Nation. Chicago: University of Chicago Press.

I993a The Black Atlantic: Modernity and Double Consciousness. Cambridge, MA: Harvard University Press.

I993b Small Acts: Thoughts on the Politics of Black Culture. London: Serpent's Tail.

2000 Against Race: Imagining Political Culture Beyond the Color Line. Cambridge, mA: Harvard University Press.

Gregory, Angela

2005 California Dreaming. New Zealand Herald, I 5 January. http://www .nzherald.co.nz/world/news/article.cfm?c_id=2\&objectid $=10006659$ [accessed 2 April 20I0] 
Hall, Stuart

I990 Cultural Identity and Diaspora. In Identity, Community, Culture, Difference, edited by Jonathan Rutherford, 222-237. London: Lawrence and Wishart.

I99ra The Local and the Global: Globalization and Ethnicity. In Culture, Globalization and the World-System: Contemporary Conditions for the Representation of Identity, edited by Anthony D King, 19-40. Binghamton, NY: Department of Art and Art History, State University of New York, Binghamton.

I99Ib Old and New Identities, Old and New Ethnicities. In Culture, Globalization and the World-System: Contemporary Conditions for the Representation of Identity, edited by Anthony D King, 4I-68. Binghamton, NY: Department of Art and Art History, State University of New York, Binghamton.

I992 The Question of Cultural Identity. In Modernity and Its Futures, edited by Stuart Hall, David Held, and Tony McGrew, 273-3 I6. Cambridge, UK: Polity.

Hall, Stuart, Charles Critcher, Tony Jefferson, John Clarke, and Brian Robert, editors

I978 Policing the Crisis: Mugging, the State and Law and Order. London: Macmillan.

Hau'ofa, Epeli

I993 Our Sea of Islands. In A New Oceania: Rediscovering Our Sea of Islands, edited by Vijay Naidu, Eric Waddell, and Epeli Hau'ofa, 2-ı 6. Suva: School of Social and Economic Development, The University of the South Pacific. Reprinted in The Contemporary Pacific 6:147-I6I (I994).

Henderson, April K

I999 Gifted Flows: Netting the Imagery of Hip Hop Across the Samoan Diaspora. Master's thesis, Pacific Islands Studies, University of Hawai'i, Mānoa.

2006 Dancing Between Islands: Hip Hop and Samoan Diaspora. In The Vinyl Ain't Final: Hip Hop and the Globalization of Black Popular Culture, edited by Dipannita Basu and Sidney J Lemelle, I80-I99. London: Pluto Press.

2007 Gifted Flows: Engaging Narratives of Hip Hop and Samoan Diaspora. $\mathrm{PhD}$ thesis, History of Consciousness, University of California, Santa Cruz.

Julien, Isaac, director and writer

I994 The Darker Side of Black. Documentary film. London: в вС Arena.

Kelley, Robin D G

I994 Kickin’ Reality, Kickin’ Ballastics: “Gangsta Rap” and Postindustrial 
Los Angeles. In Race Rebels: Culture, Politics, and the Black Working Class, I83-227. New York: The Free Press.

Kopytko, Tania

I99I Dance in Palmerston North: A Study in Human Movement Systems and Social Identity in a New Zealand Community. PhD dissertation, Social Anthropology and Ethnomusicology, Queens University of Belfast.

I986 Breakdance as an Identity Marker in New Zealand. Yearbook of Traditional Music I 5:2 I-27.

Macpherson, Cluny

2005 History and Status of Samoan Diaspora Studies. Journal of Samoan Studies I:9 I-I09.

Marcus, George

I998 Ethnography through Thick and Thin. Princeton, NJ: Princeton University Press.

McClary, Susan

I 985 Afterword: The Politics of Silence and Sound. In Noise: The Political Economy of Music, by Jacques Attali, I49-I60. Minneapolis: University of Minnesota Press.

Mitchell, Tony

I996 Popular Music and Local Identity: Rock, Pop and Rap in Europe and Oceania. London: Leicester University Press.

Mitchell, Tony, editor

200 I Global Noise: Rap and Hip-Hop Outside the USA. Hartford, ст: Wesleyan University Press.

O’Malley, Julia

2006 “I Want Peace," Leader tells Polynesians. Anchorage Daily News, 2 July. Archived at http://www.samoanmusicandvideo.com/index.php?option $=$ com_content\&task=view\&id=I30\&Itemid=44 [accessed I 5 March 2010]

Pouesi, Daniel

I994 An Illustrated History of Samoans in California. Carson, CA: Kin Publications.

Pukui, Mary Kawena

I983 'Ōlelo No'eau: Hawaiian Proverbs and Poetical Sayings. Honolulu: Bishop Museum Press.

Rees, Peter

2007 Dangerous Minds. Spasifik I9 (March/April): 26-28.

Rose, Tricia

I994 Rap Music and the Demonization of Young Black Males. USA Today (May): 35-36. 
Salesa, [Toelesulusulu] Damon I

2003 “Travel-Happy” Sāmoa: Colonialism, Samoan Migration and a "Brown Pacific." New Zealand Journal of History 37 (2): I 7 I-I 88.

Savage [Demetrius Savelio]

2008 Savage Island. Hip hop album. Auckland: Dawn Raid Entertainment. Released in New Zealand in 2009.

Scott, Mark

I985 StreetAction Aotearoa. Auckland: Arohanui Publications.

Simanu, 'Aumua Mata'itusi

2002 'O Si Manu a Ali'i. Honolulu: University of Hawai'i Press.

Simei-Barton, Paul

I993 The Contest. Auckland: Pacific Theatre Company.

Sissons, Jeffrey

I99I Te Waimana, the Spring of Mana: Tuboe History and the Colonial Encounter. Dunedin, NZ: University of Otago Press.

Stokes, Jon

2005 Don't Blame Hip-hop for Street Violence Says Local Artist. New Zealand Herald, 29 October. http://www.nzherald.co.nz/section/6/story .cfm?c_id=6\&objectid= 10352565 [accessed 27 April 2007]

Sutter, Frederic

I989 The Samoans: A Global Family. Honolulu: University of Hawaici Press.

Tamati, Sara

2009 Digitally recorded interview, Wellington, New Zealand, I 2 June.

Theroux, Paul

1992 The Happy Isles of Oceania: Paddling the Pacific. London: Hamish Hamilton.

Trask, Haunani-Kay

I999 Writing in Captivity: Poetry in a Time of Decolonization. In Inside Out: Literature, Cultural Politics, and Identity in the New Pacific, edited by Vilsoni Hereniko and Rob Wilson, I7-26. Lanham, MD: Rowman \& Littlefield.

Wendt, Albert

1973 Sons for the Return Home. Auckland: Longman Paul Ltd.

I976 Towards a New Oceania. Mana Review I (I): 49-60.

I986 The Contest. Landfall I 5840 (2): I 44-I 53.

I987 Novelists and Historians and the Art of Remembering. In Class and Culture in the South Pacific, edited by Antony Hooper, Steve Britton, Ron Crocombe, Judith Huntsman, and Cluny Macpherson, 78-9I. Auckland: Centre for Pacific Studies; Suva: Institute of Pacific Studies, University of the South Pacific. 
2004 The Songmaker's Chair. Wellington: Huia Publishers.

2009 The Adventures of Vela. Wellington: Huia Publishers.

Whimp, Graeme

2007-2008 The Great Hip Hop Grant Scandal. In Watching the Kiwis, special issue of the Journal of New Zealand Studies NS 6-7 (October 2007-October 2008): IOI-I 20.

\section{Abstract}

This essay discusses Albert Wendt's incorporation of elements of hip hop culture in his literary and dramatic writing, and reflects on the relevance and usefulness of Wendt's work to the author's research on Samoan involvement in hip hop music, dance, and visual art. The widespread popularity of hip hop among diasporic Samoans is noted, as are the tendencies among some in Samoan communities to simplistically dismiss or criticize hip hop involvement as a sign of culture loss or a cause of disruptive behavior. In light of such critiques, the author credits Wendt for his consistent receptiveness to hip hop and the "space-making" gestures his work offers for a nascent Pacific hip hop arts movement.

KEYWORDS: Samoans, hip hop, rap music, poetry, theater, Albert Wendt 